\title{
Pentingnya mendidik problem solving pada anak melalui bermain
}

\author{
Lina Dani Lestari \\ Pendidikan Guru Pendidikan Anak Usia Dini, FKIP, Universitas Sebelas Maret \\ Jalan Ir. Sutami 36 Kentingan, Jebres, Surakarta, Jawa Tengah, Indonesia \\ E-mail: linadani8899@student.uns.ac.id
}

\begin{tabular}{|c|c|}
\hline ARTICLE INFO & ABSTRACT \\
\hline $\begin{array}{l}\text { Article history: } \\
\text { Received:27-05-2020 } \\
\text { Revised:10-06-2020 } \\
\text { Accepted: } 20-06-2020 \\
\text { Keywords: } \\
\text { problem solving } \\
\text { bermain, } \\
\text { anak }\end{array}$ & $\begin{array}{l}\text { Masalah yang dihadapi anak tidak sama dengan masalah yang dihadapi orang } \\
\text { dewasa, tetapi anak harus memiliki kemampuan problem solving yang bisa } \\
\text { membantu mereka mengatasi masalah tersebut dengan baik, sehingga kemampuan } \\
\text { tersebut akan terus berkembang, salah satunya dalam kemampuan kognitif. Anak usia } \\
\text { dini perlu memiliki kemampuan problem solving yang bertujuan untuk membantu } \\
\text { mereka mengatasi persoalan dengan baik dalam mengatasi permasalahan dalam } \\
\text { kehidupan sehari-hari seperti masalah berebut mainan dengan teman sebaya, } \\
\text { kesulitan memahami aturan bermain dan lain-lain. Problem solving tidak hanya } \\
\text { berguna untuk menyelesaikan masalah mereka sehari-hari, tetapi } \\
\text { keterampilan problem solving juga bermanfaat saat anak harus mengeksplorasi } \\
\text { dunianya atau saat anak mengerjakan tugas-tugas di sekolah. Keterampilan problem } \\
\text { solving akan berbeda pada setiap anak sesuai tahapan usianya dan tahap } \\
\text { perkembangannya. Keterampilan memecahkan masalah berkaitan dengan bagaimana } \\
\text { anak berpikir, memahami, dan mendapatkan pemahaman akan dunianya, termasuk } \\
\text { juga kemampuan mengingat, memecahkan masalah, dan membuat keputusan. } \\
\text { Metode penelitian dalam artikel ini menggunakan metode studi literatur atau } \\
\text { penelitian kepustakaan dengan mengumpulkan berbagai sumber yang berkaitan } \\
\text { dengan Metode pembelajaran problem solving merupakan salah satu metode } \\
\text { pembelajaran yang mencerminkan atau dilandasi oleh filsafat konstrukstivisme dalam } \\
\text { pendidikan anak usia dini, metode problem solving bisa dilakukan dengan cara } \\
\text { bermain seperti bermain puzzle, maze, bongkar pasang dan tangram. }\end{array}$ \\
\hline
\end{tabular}

Problems faced by children are not the same as problems faced by adults, but children must have problem solving abilities that can help them overcome these problems well, so that these abilities will continue to develop, one of which is cognitive ability. Early childhood needs to have problem solving abilities that aim to help them overcome problems well in overcoming problems in everyday life such as the problem of fighting over toys with peers, difficulty understanding the rules of play and others. Problem solving is not only useful for solving their daily problems, but problem solving skills are also useful when children have to explore their world or when children do tasks in school. Problem solving skills will be different in each child according to stages of age and stages of development. Problem solving skills are related to how children think, understand, and gain an understanding of their world, including the ability to remember, solve problems, and make decisions. Problem solving learning method is one of the learning methods that reflects or is based on the philosophy of constructivism in early childhood education, problem solving methods can be done by playing such as playing puzzles, mazes, loading pairs and tangram.

\section{PENDAHULUAN}

Pendidikan Anak Usia Dini adalah suatu upaya pembinaan yang ditujukan bagi anak sejak lahir sampai dengan usia lahir hingga usia 6 tahun, yang dilakukan secara menyeluruh, mencakup semua aspek perkembangan dengan memberikan stimulasi perkembangan supaya anak dapat tumbuh dan berkembang dengan optimal. Pendidikan anak usia dini (PAUD) telah dimasukan secara tegas dalam pasal tersendiri (pasal 28), undang-undang system pendidikan nasional nomor 20 tahun 2003, sedangkan pada pasal 1 butir 14 dikemukakan bahwa "suatu upaya pembinaan yang ditujukan kepada anak sejak lahir sampai dengan 6 tahun yang dilakukan melalui rangsangan pendidikan untuk membantu pertumbuhan dan perkembangan jasmani dan rohani agar anak memiliki kesiapan dalam memasuki pendidikan lebih lanjut". Hal ini merupakan perwujudan dari yang telah diamanatkan oleh UUD 1945, yaitu mencerdaskan kehidupan bangsa. 
Aspek perkembangan anak usia dini meliputi aspek nilai agama dan moral, fisik motorik, bahasa, sosial- emosional, dan seni. Salah satu bidang pengembangan yang sangat penting dan perlu diperhatikan oleh guru dan orang tua dalam pembelajaran bidang aspek perkembangan kognitif. Intelegensi atau kognitif merupakan "kemampuan untuk memecahkan msalah atau untuk mencipta karya yang dihargai dalam suatu kebudayaan atau lebih", Gardner (dalam Susanto, 2011: p 47) dalam (PGPAUD et al., n.d.) menyatakan bahwa "kognitif merupakan pikiran yang dapat digunakan dengan cepat dan tepat untuk mengatasi suatu situasi untuk memecahkan masalah". (K. Pendidikan \& Kebudayaan, 2015) menyebutkan bahwa kognitif meliputi tiga aspek. Pertama, belajar dan pemecahan masalah, mencakup kemampuan memecahkan masalah sederhana dalam kehidupan sehari-hari. Kedua, berpikir logis, mencakup berbagai perbedaan, klasifikasi, pola, berinisiatif, berencana, dan mengenal sebab-akibat. Ketiga, berpikir simbolik, mencakup kemampuan mengenal, menyebutkan, dan menggunakan konsep bilangan.

Piaget (2007: p 240) menyimpulkan bahwa perkembangan kognitif adalah "istilah umum yang mencangkup segenap model pemahaman yakni persepsi, imajinasi, penangkapan makna, penilaian dan penalaran". Kemampuan kognitif dapat dikategorikan menjadi perkembangan kognitif pengetahuan umum dan sains, perkembangan kognitif konsep bentuk, warna, ukuran dan pola serta konsep bilangan, lambang bilangan dan huruf.

Aspek perkembangan kognitif mengajarkan anak belajar memperoleh dan dapat menggunakan bentuk bentuk representasi yang mewakili objek yang dihadapinya. Menurut Winkel (dalam Riyanto, 2010: p 48), dalam belajar kognitif terdapat 2 aktivitas yaitu mengingat dan berpikir. Aktivitas itu yang mengawali anak mempelajari, mengingat dan berpikir hingga memperoleh sebuah konsep. Salah satu model pembelajaran yang dapat meningkatkan kemampuan kognitif anak yaitu model pembelajaran berbasis masalah problem solving. Pembelajaran berbasis problem solving adalah suatu model pembelajaran yang menghadapkan peserta didik pada tantangan belajar untuk belajar, Duch (dalam Riyanto, 2010: p 285), sementara Burner (dalam Riyanto, 2010: p 13) mengatakan bahwa pembelajaran berbasis masalah diterapkan melalui pemberian masalah kepada anak sehingga anak dapat menjadi problem solver dalam memperoleh sebuah konsep. Penerapan metode problem solver salah satu kemampuan yang harus dikembangkan sejak dini, hal ini dikarenakan pemecahan masalah berkaitan dengan cara anak mengembangkan kemampuan kognitif anak dikutip dalam (Pg-paud et al., n.d.). Metode Problem solving yaitu penggunaan metode dalam kegiatan pembelajaran dengan cara melatih peserta didik untuk menghadapi berbagai masalah, baik itu masalah pribadi atau perorangan maupun masalah kelompok untuk dipecahkan sendiri atau secara bersama-sama"dalam (J. Pendidikan et al., 2015). Hal ini sangat jelas bahwa anak akan menyelesaikan masalahnya dengan menggunakan cara yang sederhana.

Kemampuan anak dalam memecahkan masalah (problem solving) juga dapat meningkatkan kemampuan kognitifnya baik dalam kemampuan berpikir maupun kreativitasnya memecahkan masalahnya sendiri, mereka masih memerlukan bantuan orang tua atau guru dalam menerapkan problem solving di dalam masalah sehari-hari.

Abu Ahmadi (2005) dalam (Utami et al., 2017) mengatakan bahwa dalam pemecahan problem-problem baru yang dihadapi diperlukan kesanggupan untuk berpikir. Oleh sebab itu, sudah sewajarnya sekolah turut bertanggung jawab mempersiapkan anak didik dengan menggunakan metode problem solving dalam mengajarkan berbagai mata pelajaran. Metode ini memusatkan kegiatan pada murid. Jadi berbeda dengan metode ceramah yang mengutamakan guru. Pada tingkat ini, anak didik belajar memecahkan masalah, memberikan respons terhadap rangsangan yang menggambarkan atau membangkitkan situasi problematik, mempergunakan berbagai kaidah yang telah dikuasainya. Menurut John Dewey (dalam Abu Ahmadi, 2005) dikutip dari (Utami et al., 2017) belajar memecahkan masalah ini berlangsung sebagai berikut : individu menyadari masalah bila dia dihadapkan pada situasi keraguan dan kekaburan sehingga merasakan adanya kesulitan.

Gagne (dalam Mulyasa, 2006) dikutip dari (Utami et al., 2017) mengatakan bahwa jika seorang peserta didik dihadapkan pada suatu masalah, pada akhirnya mereka bukan hanya sekadar pemecah masalah, tetapi juga belajar sesuatu yang baru. Hal ini bertujuan pemecahan masalah memegang peranan sangat penting baik dalam pelajaran maupun dalam disiplin ilmu lainnya, terutama agar pembelajaran berjalan dengan fleksibel dan bertujuan agar anak lebih mudah memahami konsep kehidupan dengan pemecahan masalah, sehingga dalam menyelesaikan masalahnya anak dapat berpikir secara logis dan sistematis. 


\section{METODE}

Metode penelitian dalam artikel ini menggunakan studi literatur atau penelitian kepustakawan dengan mengumpulkan berbagai sumber yang berkaitan dengan materi pentingnya mendidik problem solving pada anak usia dini melalui metode bermain. Penelitian ini disebut sebagai penelitian kepustakaan dikarenakan data-data atau bahan-bahan yang digunakan dalam menyelesaikan penelitian tersebut diperoleh dari perpustakaan baik dari sumber yang berupa buku, ensiklopedi, kamus, jurnal,dokumen dan sebagainya. Penelitian kepustakawan juga merupakan metode dalam pencarian, mengumpulkan dan menganalisis sumber data untuk diolah dan disajikan dalam bentuk laporan kepustakawan.

Sebuah studi literatur juga merupakan survei dan pembahasan literatur pada bidang tertentu dari suatu penelitian. Studi ini merupakan gambaran singkat dari apa yang telah dipelajari, argumentasi, dan ditetapkan tentang suatu topik, dan biasanya diorganisasikan secara kronologis atau tematis. Menurut Sugiyono, studi kepustakaan berkiatan dengan kajian teoretis dan referensi lain yang berkiatan dengan nilai, budaya dan norma yang berkembang pada situasi sosial yang diteliti, selian itu studi kepustakaan sangat penting dalam melakukan penelitian, hal ini dikarenakan penelitian tidak akan lepas dari literatur-literatur ilmiah (Sugiyono, 2012: p 291)

\section{HASIL DAN PEMBAHASAN}

Hasil

\section{Problem solving}

Muhammad (2012) dalam (Sutina \& Indarto, n.d.) mengatakan bahwa metode problem solving yaitu suatu proses mental yang merupakan suatu bagian dari proses masalah yang lebih luas mencakup temuan dan pembentukan masalah tersebut. Penyelesaian masalah juga terjadi ketika suatu kondisi membutuhkan perubahan dari kenyataan yang dihadapi menuju kondisi yang diinginkan.

Metode pembelajaran problem solving berasal dari John Dewey. Metode ini bermaksud untuk memberikan latihan kepada anak untuk berpikir. Metode ini juga dapat menghindarkan anak untuk kesimpulan yang tergesa-gesa, menimbang-nimbang kemungkinan berbagai pemecahan, dan menangguhkan pengambilan keputusan sampai terdapat bukti-bukti yang cukup (Abdul Kadir Musyik, 1981) dalam (Utami et al., 2017). Metode pembelajaran ini merupakan salah satu metode pembelajaran yang mencerminkan atau dilandasi oleh filsafat teori konstrukstivisme. Kontruktivisme ialah suatu teori filsafat pengetahuan yang menekankan bahwasanya pengetahuan kita merupakan hasil konstruksi atau pembentukan yang berasal dari dir sendiri (Matthews, 1994) dalam (Utami et al., 2017). Pengetahuan bukanlah imitasi dari kenyataan melainkan pengetahuan merupakan akibat dari suaty kontruksi kognitif dari kenyataan ataupun aktivitas yang terjadi padaseoang siswa atau peserta didik.

\section{Kemampuan problem solving untuk anak usia dini}

Kemampuan problem solving pada anak usia dini merupakan salah satu kemampuan yang harus dikembangkan sejak dini karena kemampuan ini berkaitan dengan meningkatkan kognitif pada anak. Beaty (1994) \& Wortham (2006) dalam (Syaodih et al., 2018) menyatakan bahwa kemampuan memecahkan masalah pada anak usia dini merupakan suatu kemampuan anak untuk menggunakan pengalamannya dalam merumuskan hipotesis, mengumpulkan data, membuat keputusan tentang hipotesis, dan merumuskan kesimpulan tentang informasi yang diperoleh dalam proses ilmiah. Menurut Brewer \& Scully, et al. (Wortham, 2006), dalam (Syaodih et al., 2018) menyatakan bahwa pemecahan masalah pada anak usia dini meliputi keterampilan, melakukan observasi, mengelompokkan, membandingkan, mengukur, mengkomunikasikan, melakukan eskperimen, menghubungkan, menyimpulkan dan menggunakan informasi. Pemecahan masalah juga merupakan proses suatu penemuan langkah-langkah untuk mengatasi kesenjangan yang lalu untuk proses pemecahan masalah anak melakukan suatu kegiatan dalam menerapkan konsep-konsep dan aturan-aturan yang diperoleh sebelumnya (Branca, 1980; Dahar, 1989) dalam (Syaodih et al., 2018)

Anak usia dini memiliki rasa ingin tahu yang tinggi terhadap lingkungannya. Anak memperoleh pengalaman belajar yang bermakna melalui bermain, melakukan percobaan, menemukan, dan melalui interaksi sosial. Maria (Setiasih, 2017) dalam (Syaodih et al., 2018) menyebutkan bahwa indikator keterampilan pemecahan masalah pada anak usia dini antara lain 
(1) keterampilan observasi/mengamati (observation), (2) keterampilan mengumpulkan data dan informasi (collecting), dan (3) keterampilan mengolah informasi (communicating), (4) keterampilan mengkomunikasikan informasi. Guru juga mempunyai peran sangat penting dalam meningkatkan problem solving pada anak usia dini dengan cara guru mengungkapkan masalah, mereka hendaknya menghadapkan masalah tersebut kepada anak dan mendiskusikan pemecahannya dengan mereka sehingga anak lebih menyadari pentingnya proses pemecahan masalah tersebut.

lain :

Adapun ciri-ciri model pembelajaran dalam (Syaodih et al., 2018) problem solving antara

(a.) Mengajukan pertanyaan atau masalah; Pengajaran berdasarkan masalah yang dihadapi anak bukan hanya mengorganisasikan pada prinsip ataupun ketrampilan akademik tertentu melainkan pembelajaran yang berasal dari masalah yang ada disekitar dan masalah yang penting secara pribadi bagi anak (b.) Berfokus pada keterkaitan antar disiplin; Pengajaran masalah mungkin berpusat pada mata pelajaran tertentu, masalah yang dipilih atau yang dihadapi telah dipilih dari masalah yang benar-benar nyata didalam pemecahannya agar peserta didik dapat meninjau masalah dari banyak mata pembelajarannya.(c.) Penyelidikan autentik; Metode pembelajaran ini mengharuskan anak melakukan penyelidikan secara autentik untuk mencari penyelesaian terhadap masalah yang dihadapi atau masalah yang nyata. (d.) Menghasilkan produk atau karya dan memamerkannya; Pendidik dalam menerapkan metode ini bertujuan agar suatu pembelajarannya berdasarkan masalah yang menuntut anak untuk menghasilkan suatu produk tertentu (bentuk nyata) dan peragaan yang mana menjelaskan atau mewakili bentuk penyelesaian masalah yang mereka temukan.

\section{Kemampuan problem solving menurut usia anak}

Keterampilan pemecahan masalah pada anak akan terlihat berbeda bagi anak pada setiap tahap perkembangan dan tahapan usianya. Usia setahun, anak bisa membuat pilihan-pilihan secara sederhana, seperti memilih mainan yang ingin mereka mainkan lalu juga bisa meniru orang dewasa di sekitarnya untuk memecahkan masalah sederhana.

a. Usia Batita (1-3 tahun)

Stimulasi perkembangan kognitif dan problem solving akan berbeda untuk setiap tahapan usia anak. Buku "Denver Developmental Activities" dalam (Frakenburg \& Thornton, 1989) menjelaskan bahwa anak usia batita (1-3 tahun) bisa diajak bermain permainan sederhana seperti cilukba, bermain petak umpet, membantu anak bermain atau menyusun puzzle, balok, mewarnai, dan menyediakan anak mainan dan aktivitas variatif yang membutuhkan pemecahan masalah. Berkembangnya maturitas pemahaman anak terhadap keberadaan benda dan sebab akibat sederhana, pada usia 1-3 tahun anak mulai bermain dengan tujuan dan rasa ingin tahu akibat dari tindakannya, jika kegiatan tersebut menurut anak menyenangkan anak akan mengulanginya berkali-kali. Pada usia 2 tahun, anak dapat menggunakan memorinya untuk memecahkan masalah yang berhasil dilalui pada masa-masa sebelumnya, atau yang sudah berhasil diatasi orang lain karena hal tersebut kapasitas manusia untuk memecahkan masalah terus berkembang sampai seseorang tumbuh dewasa. Kemampuan problem solving sejalan dengan perkembangan kognitif seorang anak karena problem solving merupakan kemampuan anak untuk menyerap, memikirkan, dan memahami dunianya termasuk mengingat, mencari pemecahan masalah, dan mengambil keputusan. Bertambahnya lama perhatian atau konsentrasi, anak pun mulai dapat memahami keberadaan benda, dan berusaha mengambil benda tersebut dengan berbagai cara. Anak belajar dari pengalamannya lalu kemudian memanipulasi cara mengambil sesuatu atau bermain dengan mainannya, anak mulai belajar bermain imajinatif seperti menyuapi boneka, masak-masakan, balapan mobil, dan lain-lain.

b. Usia Balita (3-4 tahun)

Pada anak usia 3-4 tahun, pendidik atau orangtua dapat mengajarkan anak membilang dan mengenal angka 1-10, lalu juga dapat melalui permainan eksperimen sederhana seperti mengelompokkan benda berdasarkan ukuran dan berat selanjutnya juga dapat memberikan anak permainan yang melatih daya ingatnya (permainan tebak-tebakan), membacakan buku cerita, dan lainnya. Dalam buku "Approaches to Learning" (Wilson \& Wilson, 2019), ketika memelajari keterampilan memecahkan masalah, anak mungkin akan mengalami fase kesal, frustrasi karena tidak dapat mencari solusi dari masalahnya. Anak mungkin akan membuang atau meninggalkan mainannya dan tidak mau lagi memainkannya, sebaiknya pendidik atau orang dewasa dapat membantu anak untuk menemukan permasalahan yang dihadapinya, kemudian memberikan 
kesempatan anak memikirkan jalan keluarnya lagi, jika anak sudah sangat frustrasi (menangis, membuang mainannya), orangtua dapat menunjukkan bagaimana cara menyelesaikan masalah dan biarkan anak mengamati kemudian mencontohnya. Terakhir yang tidak kalah pentingnya yaitu memuji usaha anak untuk menyelesaikan masalah yang dihadapinya.

c. Usia Prasekolah (usia 5-6 tahun)

Usia 5-6 tahun anak mulai berkreasi saat bermain, misalnya menggunakan potongan kertas untuk bermain masak-masakan, menyelesaikan puzzle yang lebih kompleks, dan mengelompokkan mainannya dalam (Developmental Milestones, Rebecca J. Scharf, Graham J. Scharf, dan Annemarie Stroustrup, jurnal Pediatrics in Review) (Scharf et al., 2016) . Aspek fundamental dalam perkembangan kognitif dan problem solving yang terpenting yaitu memori, kemampuan anak dalam berkreasi, perhatian atau konsentrasi, dan kecepatan memproses informasi. Apabila kemampuan anak dalam berkonsentrasi, mengingat, berkreasi, dan mengolah informasi yang didapatnya baik maka kemampuan problem solving-nya juga baik.

Keterampilan memecahkan masalah merupakan bekal untuk anak sampai saat dewasa anak mengatasi kesulitan atau hal-hal baru yang dihadapinya ketika sedang beraktivitas sehari-hari, di sekolah, atau dilingkungan sekitrnya. Anak menjadi mandiri dan tidak bergantung pada orangtua untuk menyelesaikan masalah jika ada kesulitan yang dihadapi. Anak juga terlatih untuk menjadi kreatif karena selalu dibiasakan untuk menyelesaikan masalah dengan berbagai cara yang dapat dipikirkannya.

\section{Pembahasan}

\section{Problem solving yang dilakukan melalui permainan}

Piaget mengemukakan bahwa bermain memberikan kesempatan kepada anak untuk mengasimilasi kenyataan terhadap dirinya terhadap kenyataan. Konsep pentingnya bermain di taman kanak-kanak yang bertujuan untuk menciptakan lingkungan belajar yang memungkinkan anak dapat belajar sambil bermain dan bermain seraya belajar secara efektif. Melalui bermain anak kemampuan dan potensi pada anak dapat berkembang secara optimal. Pentingnya bermain menurut Piaget dalam Riete de Vries (2002) dalam (Bobik et al., 2006) bermain merupakan wahana yang sangat penting untuk perkembangan berpikir anak. Belajar yang paling efektif untuk anak usia dini melalui suatu kegiatan yang konkret dan pendekatan yang berorientasi pada permainan karena permainan pada anak usia dini merupakan kegiatan yang kreatif dan menyenangkan. Froebel dalam Audrey Curtis (1998) dalam (Bobik et al., 2006) mengemukakan bahwa melalui bermain kreatif anak dapat mengembangkan, mengintegrasikan, dan meningkatkan semua kemampuannya karena anak lebih banyak belajar melalui bermain dan melakukan eksplorasi terhadap objek-objek dan pengalamannya tidak hanya itu anak juga dapat membangun pengetahuannya sendiri melalui interaksi sosial dengan orang dewasa pada saat mereka memahaminya dengan bahasa dan gerakan sehingga tumbuh dengan baik secara kognitif menuju berpikir verbal.

Menggunakan metode permainan juga lebih mengasyikkan dan membuat anak tidak merasa tertuntut dan tertekan dalam menerima pembelajaran, pendidik juga bisa memanfaatkan media bermain anak sebagai tempat pembelajaran tersebut, seperti dengan cara bercerita atau pada kejadian sehari-hari. Bermain adalah dunia anak yang merupakan masa keemasan untuk menbangun karakter anak. Pendidik atau orangtua bisa memilih permainan yang mendidik anak yang memiliki manfaat lebih untuk mendidik anak menjadi mandiri serta mampu menyelesaikan masalahnya sendiri. Cara mendidik anak melalui permainan adalah cara paling ideal karena tidak ada tekanan bagi anak dan anakpun dengan senang hati melakukannya. Banyak contoh permainan edukasi yang dapat diikuti anak, mengikuti beberapa permainan berikut untuk mengajarkan anak mandiri, kratif, dan mampu memecahkan masalahnya dengan sendiri:

a. Puzzle

(Soebachman, 2012) mengatakan bahwa bermain "Puzzle merupakan permainan yang terdiri atas suatu kepingan-kepingan dari satu gambar tertentu yang dapat melatih tingkat konsentrasi". (Yuliani, 2008) mengatakan bahwa menggunakan media puzzle terlihat bahwa manfaat menggunakan media puzzle yaitu anak dapat mengasah otaknya dengan mencari, menemukan, menyusun stategi, mencocokkan bentuk, melatih kesabaran dan telah memecahkan masalah sederhana yaitu menyelesaikan kepingan puzzle secara mandiri dan selesai dengan benar. Permainan puzzle yang dilakukan dengan cara menyusun kembali potongan gambar dapat melatih kemampuan anak dalam menyelesaikan sebuah masalah. Salah satu permainan jenis teka-teki ini 
bisa menjadi media bagi pendidik maupun orangtua untuk melatih anak menjadi lebih mandiri dan membantu anak mengasah kemampuan memecahkan masalahnya. Saat anak menyusun potongan puzzle, anak akan berpikir potongan gambar bagian mana yang pas untuk diterapkan dalam papan puzzle sehingga menghasilkan gambar atau bentuk yang sempurna.

Aktivitas anak menggunakan media puzzle merupakan salah satu cara dalam memberikan stimulus pada anak usia dini sehingga akan memunculkan respons berupa meningkatkan aktivitas anak dalam prosespembelajaran. Peningkatan kemampuan pemecahan masalah dikarenakan pada penggunaan media puzzle sebagai alat untuk melatih kemampuan anak, kemampuan tersebut meningkat karena saat bermain terjadilah proses membangun pengetahuan yang sudah dimiliki dan membangun pengetahuan baru dengan anak mengaitkan pengetahuan yang sudah didapatkan dengan keterampilan yang nyata dan dilakukan langsung oleh anak, hal ini membuktikan bahwa teori konstruktivisme yang dikemukakan oleh Haenilah (2015) merupakan teori yang mendasari dalam hal ini.

b. Maze

Permainan yang dapat mendidik anak didalam menyelesaikan masalah selanjutnya adalah Maze. Maze merupakan sebuah permainan yang menggunakan lajur berliku dan juga sempit. Permainan ini juga dapat menemukan jalan buntu ataupun rintangan. Maze yang terbuat dari kertas karton lengkap dengan berbagai perintah seperti menemukan jalan menuju rumah, jalan menuju ke sekolah, mencocokkan makanan untuk hewan, mencocokan warna buah dan lainnya. Anak hanya membutuhkan pensil untuk memperjelas jalan atau lajur yang dipilih supaya lebih jelas dengan perintah yang ada di maze tersebut. Orangtua juga bisa membuat maze sendiri di rumah dengan menggunakan barang-barang yang ada atau membuat gambar maze di kertas lalu ajak anak mencari jalan keluar dengan membuat jejak garis pada gambar tersebut dapat juga dibuat dengan warna dan gambar-gambar atraktif agar anak lebih tertarik. Kegiatan dengan menggunakan media maze dapat dilakukan sambil bermain mampu untuk mengembangkan perkembangan kognitif anak ataupun konsep bilangan anak. Melalui permainan maze anak dapat mengekspresikan diri dalam berkreatifitas dan dalam menyelesaikan masalah yang ada dihadapan anak serta anak mampu untukmembedakan angka-angka yang terdapat pada jalan-jalan setapak di dalam kolom maze tersebut.

c. Bongkar Pasang

Permainan bongkar pasang yaitu salah satu alat permainan edukatif yang berguna untuk anak dan merupakan alasan yang baik bagi guru menggunakan permainan tersebut dalam proses pembelajaran. Patmonodewo (Muzamil, 2010: p 46), dalam (Hasnawati et al., 2016)mengatakan bahwa "kata bongkar pasang berasal dari bahasa inggris yaitu puzzle yang berarti teka-teki atau bongkar pasang, permainan bongkar pasang merupakan salah satu media yang sederhana yang dimainkan dengan cara dibongkar dan dipasang". Hal ini dapat dipahami bahwa media bongkar pasang adalah alat permainan edukatif yang dapat merangsang berbagai kemampuan anak (aspek perkembangan anak), permainan ini dimainkan dengan cara membongkar kepingan bongkar pasang lalu memasang (mencocokkan) berdasarkan pasangannya, baik permainan bongkar pasang dua dimensi atau permaianan bongkar pasang tiga dimensi. Ismail (2009: p 199) dalam (Hasnawati et al., 2016) mengatakan bahwa "Permainan bongkar pasang adalah permainan yang menyusun suatu gambar atau benda yang telah dipecah dalam beberapa bagian, yang bermanfaat untuk melatih kecerdasan inteligensi anak" sehingga dapat dipaami bahwa media permainan bongkar pasang memiliki manfaat yang sangat besar dikarenakan dengan permainan ini anak dapat menyatukan kembali posisi gambar pada tempatnya yang sesuai. Permainan ini lebih mementingkan proses dari pada hasil, selain itu permainan bongkar pasang juga melibatkan koordinasi mata dan tangan, sehingga cocok untuk anak-anak. Muzamil (2010:p 78) dalam (Hasnawati et al., 2016) mengatakan bahwasanya ada bbeberapa bentuk permainan bongkar pasang, antara lain bongkar pasang konstruksi (construction puzzle), bongkar pasang batang (puzzle stick), bongkar pasang lantai, bongkar pasang huruf, bongkar pasang hijaiyah, bongkar pasang buah-buahan, bongkar pasang binatang, bongkar pasang transportasi, bongkar pasang logika, bongkar pasang lego, bongkar pasang duplo, bongkar pasang building block, bongkar pasang jigsaw, dan bongkar pasang papan pasak.

Tedjasaputra (2011:p 71) dalam (Hasnawati et al., 2016) mengatakan bahwasanya langkahlangkah penggunaan media permainan bongkar pasang antara lain: a) Perhatikan gambar yang terdapat pada permainan bongkar pasang secara saksama; b) Bongkar (lepaskan) kepingankepingan permainan bongkar pasang; c) Mulai memasangkan kepingan-kepingan bongkar pasangdengan menggunakan jari-jari tangan sesuai dengan pasangannya: dan d) Pastikan 
kepinagan-kepingan bongkar pasang terpasang dengan baik sehingga membentuk suatu gambar atau bentuk yang utuh. Berdasarkan pemaparan tersebut dapat diketahui bahwa permainan bongkar pasang sangat penting dalam mengembangkan aspek-aspek perkembangan pada anak usia dini dan proses penggunaannya juga sangat mudah bagi anak usia dini. Aspek yang dikembangkan yaitu aspek kognitif saat anak memikirkan susunan yang mana yang akan di cocokan dari permainan bongkar pasang tersebut, aspek motorik halus anak dapat menyusun bongkar pasang dengan menggunakan tangan maka motorik halus anak akan berkembang, aspek bahasa anak dapat menyebutkan gambar/bentuk yang terbentuk dari susunan bongkar pasang tersebut sehingga dapat menambah kosa kata (perbendaharaan kata), aspek sosial emosional anak bisa bekerjasama ataupun bersosialisasi dengan temannya dalam menyusun permainan bongkar pasang dan bisa melatih kesabaran anak, ketekunan dan ketelitian dalam menyusun bongkar pasang. Hal ini dapat dipahami bahwa manfaat dari permainan bongkar pasang yaitu dapat melatih konsentrasi anak dan dapat meningkatkan serta mengembangkan berbagai aspek-aspek perkembangan kecerdasan dan kemampuan yang sudah dibawa anak sejak dia lahir tersebut. Hal ini secara tidak langsung anak telah belajar memecahkan masalah melalui permainan ini anak tanpa sadar dituntut untuk berimajinasi dan memiliki pemikiran yang kreatif agar dapat mencari solusi yang tepat dari suatu permasalahan.

\section{d. Tangram}

Tangram merupakan permainan edukatif di bidang matematika. Permainan ini dikenal permainan yang sudah lama dan cukup banyak dikenal oleh masyarakat luas. Kata Tang dan Gram yang artinya tujuh keping ajaib, di dunia modern biasa disebut sebagai puzzle China. Permainan ini terdiri dari tujuh keping geometri aneka warna yang sangat bermanfaat dalam pendidikan usia dini, aneka bentuk geometri seperti bentuk bujur sangkar, persegi panjang, segitiga, dan aneka bentuk geometri lainnya. Tidak hanya sebuat permainan yang menyenangkan, tangram juga melingkupi tujuh aspek yang dibutuhkan dalam perkembangan kecerdasan, yaitu aspek kognitif meliputi pengenalan bentuk dan warna benda di sekitar serta mempunyai banyak manfaat karena beraneka warna dan bentuknya. Aspek bahasa, perbendaharaan kata menjadi meningkat seiring dengan kemampuan anak menjelaskan bentuk yang dia buat melalui susunan geometri tangram. Dengan meningkatkan kecerdasan bahasa pada anak selain itu agar manfaat ini benar-benar maksimal tangram harus dimaninkan bersama orangtua maupun guru serta orang yang bisa membimbing anak karena dengan merangkai aneka bentuk geometri menjadi benda lain, anak dapat menebak bentuk benda yang telah dirangkainya contohnya bentuk ikan, bentuk rumah dan lainnya. Saat anak menebak kata tersebut, anak banyak belajar kosakata baru dan jika anak belum memahami atau tidak paham, guru maupun orangtua dapat menjelaskan maksud dari bentuk tersebut sehingga anak mendapatkan kosakata yang baru. Aspek karakter, dalam permainan ini anak tidak perlu membutuhkan banyak energi karena tangram bukanlah permainan fisik yang mengeluarkan energi banyak, sebaliknya tangram merupakan permainan kecerdasan mengelola energi, jadi yang dibutuhkan adalah kecerdasan dalam mengontrol energi karena jika anak banyak gerak akan sulit untuk menyelesaikan permainan ini. Permainan ini membutuhkan fokus yang tinggi seperti bagaimana anak mengelola emosinya untuk fokus menyelesaikan permainan, teliti, sabar dan pantang menyerah, jadi karakter yang terbentuk pada diri anak saat meminkan permainan ini akan terbentuk. Aspek motorik halus, jari-jemari dan tangan anak akan lebih banyak bekerja melalui permainan ini karena permainan ini membutuhkan tingkat kesabaran dan ketelitian yang tinggi maka permainan ini tergolong sebagai permaian yang berguna untuk mengembangkan motorik halus pada anak. Orangtua bisa membuat tangram sendiri lalu mengajak anak untuk mewarnainya, pada saat menyusun tangram dibutuhkan koordinasi antara ketelitian dan gerak tangan. Aspek daya imajinasi dan kreativitas anak yang semakin meningkat melalui tangram, Kemampuan problem solving juga semakin terasah melalui cara anak belajar merangkai keping-keping tangram menjadi bentuk yang anak bayangkan sebelumnya. Perkembangan daya imajinasi inilah yang bisa meningkatkan kreativitas pada anak. Aspek sosial, karena ini merupakan yang dilakukan oleh beberapa pemain maka aka sangat berguna untuk mengembangkan ketrampilan anak dalam berteman, bergaul serta bersosialisasi pada anak lainnya terbentuk melalui komunikasi yang tercipta saat anak menjelaskan bentuk-bentuk yang dihasilkannya. Terakhir aspek fisik, aktivitas ini merupakan aktivitas yang paling baik untuk kesehatan karena anak-anak akan aktif dalam bergerak saat memainkan permainan ini, walaupun 
tampak tidak terlalu menguras energi namun permainan ini tetap menuntut anak bergerak aktif, seperti saat mengambil keping, mewarnai, atau saat menyusun keping tangram. Permainan ini menjadi pilihan yang baik bagi orangtua maupun guru untuk diberikan pada anak agar anak tumbuh menjadi anak yang cerdas dan sehat.

Tidak hanya mampu mendidik anak agar lebih mandiri dengan konsep bukan hanya dengan yang menggunakan alat saja tetapi mengajarkan anak menyelesaikan masalah juga dapat dilakukan dengan cara berbicara dan permaian yang hanya melibatkan kemampuan bahasa, seperti teka-teki atau permainan tebak kata. Melalui diskusi sederhana orangtua maupun guru juga bisa memberikan pemahaman secara perlahan pada anak tentang bagaimana menyelesaikan masalah dengan baik dan benar, sehingga anak tidak perlu menggunakan agresi fisik seperti memukul, menggigit ataupun mencubit dalam menyelesaikan sebuah masalah, orangtua maupun guru memberikan sebuah contoh pada anak tentang bagaimana cara mengontrol sikap yang baik, guna melatih kemampuan anak untuk bisa mandiri serta kreatif.

\section{SIMPULAN}

Metode problem solving ini dapat menghindari anak dari membuat suatu kesimpulan yang tergesa-gesa, anak dapat mempertimbangkan masalahnya karena pada metode problem solving ini merupakan salah satu aspek kemampuan berpikir kritis yang perlu dikembangkan pada setiap individu, karena pada prinsipnya masalah ada dalam kehidupan sehari-hari (Setiasih, 2010). Metode ini juga anak juga memiliki kemampuan intelektual yang bersifat kompleks, yaitu kemampuan memahami konsep-konsep, kaidah-kaidah dan dapat menerapkan konsep-konsep dan kaidah-kaidah itu dalam memecahkan masalah yang dihadapi. Hal ini dapat diketahui bahwa kemampuan pemecahan masalah anak usia dini menggunakan kemampuan untuk menggunakan pengalamannya dalam merumuskan hipotesis, mengumpulkan data, membuat keputusan tentang hipotesis. Kemampuan kognitif anak juga dapat diamati dari aktivitas mental (otak) untuk memperoleh pengetahuan yang didapat dari pengalamannya sendiri. Pengaturan aktivitas mental dengan menggunakan kaidah dan konsep yang telah dimiliki anak yang kemudian direpresentasikan melalui tanggapan, gagasan, atau lambang. Anak yang dapat memecahkan masalah sendiri menunjukkan bahwa kemampuan kognitif dalam berpikir dan berkreatifitas sehingga anak dapat berkembang dengan baik. Jadi sangatlah penting melatih anak untuk dapat menyelesaikan masalahnya sendiri tanpa bantuan orang lain. Hal ini juga dapat dilakukan dengan cara yang sangat menyenangkan tanpa memberikan beban pada anak yaitu dengan bermain. Piaget mengemukakan bahwa bermain memberikan kesempatan kepada anak untuk dapat mengasimilasi kenyataan terhadap dirinya terhadap kenyataan. Konsep pentingnya bermain di taman kanakkanak yang bertujuan untuk menciptakan lingkungan belajar yang memungkinkan anak dapat belajar sambil bermain dan bermain seraya belajar secara efektif. Melalui bermain anak kemampuan dan potensi pada anak dapat berkembang secara optimal. Adapun permainan edukasi yang dapat dilakukan anak untuk dapat memecahkan masalah yaitu puzzle, maze, bongkar pasang dan tangram.

\section{UCAPAN TERIMA KASIH}

Dengan terselesainya penulisan dan pencarian sumber yang telah dilakukan, penulis mengucapkan terimakasih kepada pihak-pihak yang bersangkutan yang telah membantu khususnya dosen pengampu mata kuliah Seminar Paud yaitu Ibu Ruli Hafidah dan Ibu Novita Eka Nurjannah karena telah mendukung serta memotivasi para mahasiswa untuk berlatih dalam melakukan penulisan artikel ilmiah dan kelak nantinya akan berguna pada penulisan-penulisan lainnya. Penulis juga mengharapkan agar artikel ilmiah yang ditulis dapat menjadi wahana transformasi pengetahuan antara sekolah dan masyarakat. 
Jurnal Pendidikan Anak, Volume 9 (2), Tahun 2020

Lina Dani Lestari

\section{DAFTAR PUSTAKA}

Bobik, P., Boschini, M. J., Gervasi, M., Grandi, D., Kudela, K., \& Rancoita, P. G. (2006). Primary helium cr inside the magnetosphere: A transmission function study. Astroparticle, particle and space physics, detectors and medical physics applications proceedings of the 9th Conference, 909-916. https://doi.org/10.1142/9789812773678_0145

Frankenburg, W.K., \& Thornton S.M. (1989). Denver developmental activities. Journal of Developmental \& Behavioral Pediatrics. https://doi.org/10.1097/00004703-19890200000005.

Hasnawati, Ahmad, A., \& Afendi, J. (2016). Implementasi permainan bongkar pasang dalam melejitkan berbagai aspek perkembangan anak usia dini pada Paud It Ar-Rahmah Banda Aceh. Jurnal Ilmiah Mahasiswa Pendidikan Anak Usia Dini, 1(1), 19-28. https://doi.org/10.1017/CBO9781107415324.004

Pendidikan Usia Dini. (2015). Penerapan metode problem solving berbantuan media media Jurusan Bimbingan Konseling Fakultas Ilmu Pendidikan Universitas Pendidikan Ganesha e-journal PG PAUD Universitas Pendidikan Ganesha. 3(1).

Pendidikan, K., \& Kebudayaan, D. A. N. (2015). Menteri pendidikan dan kebudayaan republik indonesia nomor 137 Tahun 2013 Tentang. Gitin, L. (n.d.). The Pupil Personnel Administrato.

Pg-paud, P. S., Pendidikan, F. I., Surabaya, U. N., Purbaningrum, D. E., \& Kes, M. (n.d.). Pengaruh penerapan pembelajaran berbasis masalah tipe problem solving kelompok $B$ di tk belia krratif surabaya. Lusy Ardiana Abstrak. 1-5.

Scharf, R. J., Scharf, G. J., \& Stroustrup, A. (2016). Developmental milestones. Pediatrics in review. https://doi.org/10.1542/pir.2014-0103

Sutina, D., \& Indarto, W. (n.d.). Effect of method of problem solving skills of science in children aged 5-6 years in TK Al- munawarah merbau bay district belitung. 1-12

Syaodih, E., Setiasih, O., Romadona, N. U. R. F., \& Handayani, H. (2018). Pengembangan kemampuan pemecahan masalah anak usia dini dalam pembelajaran proyek di taman kanak-kanak. Jurnal Pendidikan Anak, 12(1), 29-36.

Utami, L. O., Utami, I. S., \& Sarumpaet, N. (2017). Penerapan metode problem solving dalam mengembangkan kemampuan kognitif anak usia dini melalui kegiatan bermain. Tunas Siliwangi, 3(2), 175-180.

Wilson, J. L., \& Wilson, J. L. (2019). Approaches to learning. In student learning in higher education. https://doi.org/10.4324/9780429445569-7 